\title{
Duration of Hormonal Contraception and Risk of Cervical Cancer
}

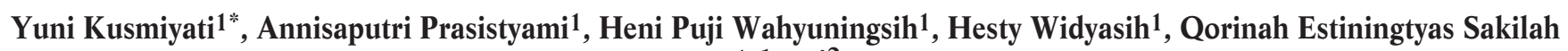 \\ Adnani2 $^{2}$
}

${ }^{1}$ Midwifery Department of Yogyakarta Health Polytechnic Ministry of Health, Indonesia, ${ }^{2}$ Midwifery Department, Faculty of Health and Environmental Sciences Auckland University of Technology, Auckland, New Zealand

\begin{abstract}
The use of long hormonal contraceptives can disrupt the balance of estrogen in the body and resulting in abnormal cell changes. By using a case-control design, this study aimed to determine the association between duration of hormonal contraception use and the risk of cervical cancer. The study population was composed of patients examined in 2018 at a cancer installation and obstetrics-gynecology polyclinic of the Central General Hospital in Yogyakarta. Random sampling yielded 95 women diagnosed with cervical cancer assigned for the case group and other 95 women with negative pap smear results for the control group. Data on the dependent variable (cervical cancer) and the independent variable (duration of hormonal contraception), based on the length of hormonal contraceptive use, were both obtained from the medical records. Assessment of cervical cancer was based on the doctor's diagnosis. Using logistic regression for data analysis, results showed that $44.7 \%$ of samples used long-term hormonal contraceptives (over five years). Length of use of hormonal contraceptives had a significant correlation with the incidence of cervical cancer ( $p$-value $<0.01$ ). Use of hormonal contraceptives for more than five years increased the risk of cervical cancer by 4.2 times $(95 \% \mathrm{Cl} 1.01-5.69)$ compared to less than five years of use after controlled by first marriage age and parity.

Keywords: Cervical cancer, duration of use, hormonal contraceptives, marriage age, parity
\end{abstract}

\section{Introduction}

Cervical cancer is a leading cause of mortality in women in the world, including Indonesia. ${ }^{1}$ This type of cancer ranks third as the cause of mortality in women the world over, with an estimated mortality rate of 15 per 100,000 women. ${ }^{2}$ While, in developing countries, including Indonesia, cervical cancer ranks as the top most common cause of death in women at about $80 \%$ of the total cases. ${ }^{3}$ The number of cervical cancer patients in Indonesia is estimated to be $90-100$ per 100,000 inhabitants per year. ${ }^{4,5,6}$ Yogyakarta is the region with the highest incidence of cancer in Indonesia, with the prevalence of cervical cancer at $1.5 \% .{ }^{7,8}$ Cervical cancer consistently ranks third in the top ten major cancers treated at the Dr. Sardjito Central General Hospital.

Cervical cancer is a disease with a relatively long

How to Cite: Kusmiyati Y, Prasistyami A, Wahyuningsih HP, Widyasih H, Adnani QES. duration of hormonal contraception and risk of cervical cancer. Kesmas: National Public Health Journal. 2019; 14 (1): 9-13. (doi:10.21109/kesmas.v14i1.2713) development period. From the precancerous stage, it takes 10 to 20 years to develop into invasive cancer. Patients can complain of severe pain that can be felt during sexual intercourse, accompanied by abnormal bleeding. When cancer has spread to the brain and lungs (pulmonary stage, IVB), the patient life will be increasingly difficult to save. ${ }^{9,1}$ Study conducted in 2017 by Yvonne, et al., showed that of 821 women diagnosed with cervical cancer, 497 (60.5\%) died during follow up. The chances of a cervical cancer patient to survive one year after diagnosis is $62 \%$; three years after diagnosis, $29 \%$; and 5 years after diagnosis, 30\%.10

Studies showed that several factors significantly correlate with cervical cancer. These are early sexual intercourse (engaged before 20 years), parity (more than three live births), and the use of hormonal contraceptives

Correspondence*: Yuni Kusmiyati, Midwifery Departement of Health Polytechnic Ministry of Health Yogyakarta, Indonesia, Phone: +62-821-38781781,E-mail: yuni_kusmiyati@yahoo.co.id

Received : October $24^{\text {th }} 2018$

Revised : May $9^{\text {th }} 2019$

Accepted : July $9^{\text {th }} 2019$ 
(exceeding five years). ${ }^{1}$ The risk factors of this type of cancer are low education; infections by Trichomonas vaginalis, bacterial vaginosis, disorders on genitals; and contraceptive use. ${ }^{11}$ The effect of exposure to different hormones on the risk of developing cancer is not yet fully understood. Duration of each hormonal contraceptive usage still needs to be examined. 12

The number of active family planning participants from 2014 to 2016 showed an upward year-to-year trend. The percentage of active family planning participants who used hormonal contraceptives ranged from $81.58 \%$ to $81.97 \%$ (injectables, $47.54 \%$; pills, $23.58 \%$; implants, $10.46 \%) .13$ The aim of this study was to determine relationship between duration of hormonal contraceptive use and incidence of cervical cancer, and to identify other factors related to cervical cancer incidence.

\section{Method}

This study used a case-control design that composed of patients examined in 2018 at a cancer installation and obstetrics-gynecology polyclinic in the Central General Hospital in Yogyakarta. 95 women diagnosed with a cervical cancer assigned for the case group, and the other 95 women with negative pap smear results for the control group. Subjects were excluded if they had never used hormonal contraceptives or if their medical record data is incomplete. The independent variable was the duration of hormonal contraceptive use, whereas the dependent variable was cervical cancer, assessed by the doctor's diagnosis recorded in each subject's medical record. The duration of hormonal contraception refers to the length of use of hormonal contraceptives (injectables, pills, and implants).

The duration of hormonal contraceptive use (injectables, pills, and implants) was categorized into two, more than five years and less than five years. Possible confounders age of marriage below 20 years old, family records of cancer, active smoking, and 3 parities or higher. For statistical analysis, chi-square test was used for bivariate analysis and the logistic regression was used for multivariate analysis. The p-value of the likelihood ratio to the chi-square was used as a guide to the subject's goodness of fit. All p-values were two-tailed and statistical significance level was set as less than 0.05. Ethical approval was granted for the study by the Ethics Committee of the Faculty of Medicine, Gadjah Mada University No.KE/KF/0561/EC/2018.

\section{Results}

The total number of subjects who participated in this 2018 study conducted at the Central General Hospital in Yogyakarta was 190 subjects consisting of 95 women diagnosed with cervical cancer as the case group and 95 women who did not have cervical cancer or had negative pap smear tests as the control group. The duration of hormonal contraceptive use (injectables, pills, and implants) was categorized into long ("> 5 years" (more than five years) and "not long" (less than five years). Table 1 presents the correlation of the duration of use of hormonal contraceptives with cervical cancer and other affecting factors.

This study investigated the correlation between the duration of use of hormonal contraceptives, the age of first marriage, parity, active smoking, and family records of cancer with cervical cancer. The use of hormonal contraceptives for more than five years led to risk 4.3 times higher of cervical cancer than if the use was less than five years. Duration of pills, injectables, and implant use have a significant correlation with cervical cancer. Women whose age at first marriage was $<20$ years presented with a 2.3 times higher risk of cervical cancer. Parity greater than 3 increased the risk of the disease by 2.5 times. No significant correlation between active smoking and family record of cancer with cervical cancer were found.

Association between cervical cancer and the duration of the use of hormonal contraceptives, the age of marriage, parity, active smoking, and family records of cancer was analyzed by logistic regression using the

Table 1. Association of the Duration of the Use of Hormonal Contraceptives, Age of Marriage, Parity, Active Smoking, Family Record of Cancer with Cervical Cancer

\begin{tabular}{|c|c|c|c|c|c|c|}
\hline \multirow[t]{2}{*}{ Variable } & \multirow{2}{*}{$\begin{array}{l}\text { Case } \\
\text { n (\%) }\end{array}$} & \multirow{2}{*}{$\frac{\text { Control }}{\mathrm{n}(\%)}$} & \multirow[t]{2}{*}{ p-Value } & \multirow[t]{2}{*}{ OR } & \multicolumn{2}{|c|}{$\mathbf{9 5} \% \mathbf{C I}$} \\
\hline & & & & & Lower & Upper \\
\hline Hormonal contraception $>5$ years & $59(62.1)$ & $26(27.4)$ & 0.01 & 4.3 & 2.35 & 8.02 \\
\hline Use of pills $>5$ years & $16(51.6)$ & $3(13.0)$ & 0.01 & 7.1 & 1.74 & 28.9 \\
\hline Use of injections $>5$ years & $32(66.7)$ & $13(35.1)$ & 0.01 & 3.6 & 1.49 & 9.11 \\
\hline Use of implants $>5$ years & $11(68.8)$ & $10(28.6)$ & 0.01 & 5.5 & 1.51 & 19.9 \\
\hline Married age $<20$ years old & $47(49.5)$ & $28(29.5)$ & 0.01 & 2.3 & 1.29 & 4.25 \\
\hline Parity $>3$ & $27(28.4)$ & $13(13.7)$ & 0.02 & 2.5 & 1.20 & 5.22 \\
\hline Active smoking & $2(2.1)$ & $0(0.0)$ & 0.49 & 2.0 & 1.75 & 2.33 \\
\hline Family record of cancer & $2(2.1)$ & $2(2.1)$ & 1.00 & 1.00 & 0.13 & 7.24 \\
\hline
\end{tabular}


Table 2. Association of Duration of the use of Hormonal Contraception and Cervical Cancer after Consideration of External Variables

\begin{tabular}{lcccccc}
\hline Variable & $\boldsymbol{\beta}$ & $\mathbf{p}$-Value & OR & & \multicolumn{2}{c}{$\mathbf{9 5 \%} \mathbf{C I}$} \\
\cline { 5 - 7 } & & & & & Lower & Upper \\
\hline Use of contraception hormonal $>5$ years & 1.435 & 0.000 & 4.2 & 1.011 & 5.692 \\
The first age of married $<20$ years & 0.659 & 0.046 & 1.9 & 0.993 & 4.847 \\
Parity $>$ 3 & 0.786 & 0.052 & 2.1 & 2.238 & 7.880 \\
\hline Notes: & & & & & \\
$\beta=$ coefficient; OR = Odds Ratio; $\mathrm{CI}=$ Confidence Interval
\end{tabular}

backward method. The first step of regression analysis was performed by bivariate selection. Only variables with p-value $\leq 0.250$ were inputted for the multivariate analysis. The analysis showed that the age of marriage and parity had $\mathrm{p}$-value $\leq 0.250$ while active smoking and family records of cancer had p-value $>0.250$, therefore the two latter variables were not included in the multivariable selection.

The results showed that the association between the duration of the use of hormonal contraceptives and cervical cancer after consideration of external variables (age of married $<20$ years and parity greater than 3 ) was significant. The period of use more than 5 years of hormonal contraceptives led to 4.2 times higher risk of cervical cancer after controlled by the age of first marriage and parity (Table 2).

\section{Discussion}

This study found an association between the duration of the use of hormonal contraceptives and cervical cancer. This strong association was marked with odds ratio (OR) of 4.2. The results of the present study are similar with or supportive of previous studies showing that the duration of the use of hormonal contraceptives was associated with cervical cancer, including a study finding that long-term use of hormonal contraceptives could lead to cervical cancer. A biologically plausible mechanism for this relationship is that hormonal contraceptives act as a tool for controlling the growth of neoplasms. The acceptors who use hormonal contraceptives are often found in cervical dysplasia. ${ }^{14}$ The use of hormonal contraceptives for more than four or five years can disrupt the balance of estrogen in the body, resulting in abnormal cell changes. Estrogen is likely to be one of the factors that can affect Human Papilloma Virus Deoxyribonucleid Acid (HPV DNA) replication. ${ }^{4}$ The length of use of each hormonal contraceptive is a factor.

Hormonal contraceptives can cause hypersecretion and the proliferation of endocervical glands. Besides, their use cause metaplasia and portio epithelial dysplasia and affects the mucous membranes of the endocervix. Hormonal contraception increases the risk of cervical cancer for women with HPV. It is suspected that gestagen triggers the carcinogenic effect of HPV.7,14

The use of hormonal contraceptives enhances mucus viscosity in the cervix, particularly oral contraceptives or injectables, thus serving to increase the risk of cervical cancer. This is because mucus viscosity tends to support the presence of carcinogenic agents carried to the cervix through sexual intercourse, including the HPV virus that is the primary cause of cervical cancer. The duration of implant contraceptives use can also increase the incidence of cervical cancer, and the mechanism of this contraception method involves hormonal action to thicken cervical mucus. The process of cervical mucus removal is the replacement of new cells and the addition of cells to the cervix to prevent the entry of sperm. If cervical mucus thickening occurs continuously and uncontrollably, the mucosal thickening will become abnormal, which can lead to cervical cancer because the resulting changes in the immature female body can damage cells in the cervix. ${ }^{15}$

Other factors such as first age of marriage and parity were statistically related to cervical cancer incidence. Engaging in early sexual intercourse can damage cervical epithelial tissues or the vagina cavity wall, making them susceptible to cell abnormalities that often result in abnormal growth. ${ }^{1}$ Women who begin sexual intercourse before 20 years old is more at risk of developing cancer cervix because, in the early adult period, the process of squamous cell metaplasia is substantially higher, thus increasing the risk of atypical squamous transformation, a condition that often develops into cervical intraepithelial neoplasia (NIS). ${ }^{16}$ Results of this study also follow previous studies showing women who had first sexual intercourse before 20 years old were 2.41 times more likely to develop cervical cancer. The exposure of the uterus to the HPV results in abnormal growth deviating into precancerous/cervical cancer. ${ }^{7}$ Married age can be associated with cervical cancer because the cervical epithelial tissues of the genital device that is not yet fully mature are susceptible to damage. When in a damaged state, the epithelial tissues of the cervix can worsen, which can lead to cell abnormalities and resulting in abnormal growth. This is especially the case if the sexual partner is already infected with HPV virus that is rapid contracting. ${ }^{3}$ 
Women with high parity are associated with the occurrence of cervical column epithelium during pregnancy. This incidence causes new dynamics of immature metaplastic epithelium that can increase the risk of cell transformation, particularly in the cervix where it can result in persistent HPV infection. ${ }^{17}$ Sylvia showed that the reproductive organs of women with multiple pregnancies are susceptible to injury, which in turn makes it easier for the HPV to cause cancer. This is especially true for multiple pregnancies with low birth spacing because damage to the epithelial tissue develops into the growth of abnormal cells that are potentially malignant. The process of labor and birth often presents an infectious virus with an opportunity to contaminate the reproductive organs in cases of poor vaginal hygiene conditions, and the resulting infection can become malignant. ${ }^{18}$

According to the American Cancer Society, if a woman has a mother or sister with cervical cancer, the risk of developing the disease is higher compared to those who do not have a family record of the disease. This is because cervical cancer can be genetically transmissible. ${ }^{19}$ However, the results of the present study indicate that women whose families had a record of cervical cancer did not influence their risk of developing the condition. This study differs from the study showing that family record of cervical cancer increases the risk of developing the disease by 2.19 times. $^{2}$ Respondents who have had cancer in their families presented with 14.93 times higher risk for cervical cancer. Especially in the nuclear family (first), cervical cancer is a vulnerability that is inherited. However, it is unclear whether the risks relating to a record of cervical cancer in the family is due to genetic susceptibility or familial influence on environmental lifestyle. ${ }^{3}$ At present, there is a need for counseling on contraceptive use, especially hormonal contraceptives, because high levels of hormonal contraceptive use by acceptors are thought to be the effect of failure to provide extensive information about the advantages and disadvantages of contraception and contraceptive services. ${ }^{20}$

The strength of this study is that the researchers conducted a long-term study of hormonal contraceptive use covering all types of contraception methods, such as pills, injectables, and implants. External variables that affect the incidence of cervical cancer such as the age at first marriage, family record of cancer, active smoking, and parities were analyzed in this study. The limitation of this study is that data sources of hormonal contraceptive use and cervical cancer were taken only from medical record. The use of medical records can cause a non-differential misclassification bias that can affect the accuracy of the disease (cervical cancer) and exposure (duration of hormonal contraception) data. To ensure the accuracy of the data, the researchers had anticipated this bias by selecting a place of study, which is the Dr. Sardjito Central General
Hospital that has a complete medical record and where all diagnoses are written by the obstetrician.

\section{Conclusion}

Duration of the use of hormonal contraceptives more than five years has a strong association with cervical cancer. Hormonal contraceptive use for more than five years increases the risk for cervical cancer by 4.2 times compared to the use of hormonal contraceptives for less than five years. Other factors such as first marriage $<20$ years and parity were also contributed to cervical cancer incidence, while smoking and family records were not contributed to the incidence of cervical cancer.

\section{Recommendation}

For all women who do not want more children should use non-hormonal long-term contraception. It is necessary to disclose to women or contraceptive acceptors using hormonal for up to five years.

\section{References}

1. Darmayanti D, Hapisah H, Kirana R. Faktor-faktor yang berhubungan dengan kanker leher rahim di RSUD Ulin Banjarmasin. Jurnal Kesehatan. 2015; 6(2): 172-77.

2. Torres PK, Garcia B, Roman B, Martinez M, Diaz Z. Risk allelic load in Th2 and Th3 cytokines genes as biomarker of susceptibility to HPV-16 positive cervical cancer: A case control study. BMC Cancer. 2016; 16 (330): 1-14.

3. Moselhy EA, Borg HM, Atlam SA. Cervical cancer: Sociodemographic and clinical risk factors among adult Egyptian females. Journal of Oncology Research and Treatments. 2016; 1(1): 1-7.

4. Meihartati T. Hubungan faktor predisposisi ibu terhadap kanker servik. Dinamika Kesehatan. 2017; 8(1): 194-201.

5. World Health Organization [homepage on the Internet]. Geneva: Cancer Country Profiles; 2014 [updated 2014 November 12; cited 2018 January 17]. Available from: https://www.who.int/cancer/country-profiles/en/

6. Pradya N. Hubungan usia dan penggunaan pil kontrasepsi jangka panjang terhadap hasil pemeriksaan IVA positif sebagai deteksi dini kejadian kanker leher rahim. Majority. 2015; 4(7): 13-18.

7. Sulistiya DP, Pramono D, Nurdiati DN. Faktor-faktor yang berhubungan dengan kejadian kanker serviks di Dr. Sardjito Central General Hospital Yogyakarta. Berita Kedokteran Masyarakat. 2017; 33(3): 12530.

8. Dinas Kesehatan DIY. Profil kesehatan DIY. Yogyakarta: Dinas Kesehatan DIY; 2017.

9. Setiati E. Waspadai 4 kanker ganas pembunuh wanita. Yogyakarta: Penerbit Andi; 2009.

10. Nartey Y, Hill PC, Amo Antwi K, Nyarko KM, Yarney J, Cox B. Factors contributing to the low survival among women with a diagnosis of invasive cervical cancer in Ghana. International Journal of Gynecological Cancer. 2017; 27(9): 1926-34.

11. Tao L. Prevalence and risk factors for cervical neoplasia: A cervical can- 
cer screening program in Beijing. BMC Public Health. 2014; 14(1185): $1-9$

12. Chih HJ, Lee AH, Colville L, Xu D, Binns CW. Condom and oral contraceptive use and risk of cervical intraepithelial neoplasia in Australian Women. Journal of Gynecologic Oncology. 2013; 25(3): 183-87

13. Kementerian Kesehatan Republik Indonesia. Profil kesehatan Indonesia 2016. Jakarta: Kementerian Kesehatan Republik Indonesia; 2017

14. Paramita S, Soewarto S, Widodo A, Sumitro SB. High parity and hormonal contraception use as risk factors for cervical cancer in East Kalimantan. Medical Journal of Indonesia. 2009; 19: 268-72.

15. Halimatusyaadiah S. Faktor-faktor risiko kejadian kanker serviks di Rumah Sakit Umum Daerah Propinsi NTB Tahun 2013-2014. Media Bina Ilmiah. 2016; 10(1): 58-63.

16. Pradipta B, Sungkar S. Penggunaan vaksin human papiloma virus dalam pencegahan kanker serviks. Majalah Kedokteran Indonesia.
2007;57(11):391-96.

17. Silitonga S, Purnamasari D. Faktor-faktor yang berhubungan dengan faktor risiko kanker serviks di RSUD Raden Mattaher Jambi Tahun 2013. Scientia Journal. 2014; 3 (1): 15-20.

18. Sylvia AP, Wilson LM. Patofisiologi konsep klinis proses-proses penyakit. Jakarta: EGC; 2014.

19. American Society of Clinical Oncology [homepage on the Internet]. American: Cervical cancer: risk factors. 2017. [updated 2017 June 22; cited 2018 January 19]. Available from: https://www.cancer.net/cancer-types/cervical-cancer/risk-factors

20. Najib. Pengetahuan klien dan kualitas pelayanan sebagai dasar pemilihan alat kontrasepsi hormonal. Kesmas National Public Health Journal. 2011; 6(3): 111-16. 